\title{
Industry 4.0 and Applications in Turkey
}

\author{
Celal Hakan Kagnicioglu ${ }^{{ }^{*}}$ \\ ${ }^{1}$ Anadolu University, Turkey
}

\begin{abstract}
The Industrial Revolution, which led to socioeconomic and cultural changes in the world, took place over a long period of time. From this point of view, it is possible to talk about three different industrial revolutions which have quite different structures and effects. With the influence of factors such as cyber-physical systems, the Internet of Objects and Services and innovations have begun the Fourth Industry Revolution, which we are in these days. Industry 4.0, a vision of the future, opens a door to product development, communication of production and service processes, the exchange of real-time information on machines and products, autonomous control and optimization in all software and hardware equipments. Although the concept of Industry 4.0 is now considered primarily for many firms, research centers and universities, there is no generally accepted definition of this idea. For this reason, there are not many publications that discuss this concept at academic level. The current literature describes the basic principles and structure of the Industry 4.0 concept and provides information on the potential effects that will arise if the Industry 4.0 transition period is completed. In this study, the definition and structure of the Industry 4.0 is explained in detail. The difficulties and risks that can be encountered during the transition phase of Industry 4.0 are also identified. This study includes various examples of Industry 4.0 applications in the world and also includes applications in pilot sectors in Turkey.
\end{abstract}

Keywords: autonomous control; industry 4.0; cyber-physical systems; internet of objects. 


\section{Introduction}

The main text, (TNR 12pt., alignment in block, spacing 1,0) text, text, text, text, text, text, Industry 4.0 gives the opportunity of increased flexibility in manufacturing, along with mass customization, better quality, and improved productivity to the companies. This opportunity permits the companies to cope with the challenges of producing increasingly individualized products with a short lead-time to market and higher quality. In order to achieve it, intelligent manufacturing is an important factor in Industry 4.0. Scarce resources are transformed into intelligent objects therefore, they are able to sense, act, and behave within a smart environment.

In industrial history Industry 4.0 indicates the fourth revolution and opens a new era for the whole manufacturing ecosystem, starting from design till to end-customer. This phenomenon also known as Intelligent or Smart Manufacturing in the industry. Industry 4.0 presents a scenario of interoperability where people, equipment, and machines of the whole value chain can connect and communicate with each other. During this two sided communication, the flow of information is crucial and essential in industry 4.0. For the operation of this system interconnected technologies devices relate to each other, collect and analyse data to generate information for the advanced analytics of the process. The results of this system will be used to support actions in the physical world.

In this study, the definition and structure of the Industry 4.0 is explained in detail.The difficulties and risks that can be encountered during the transition phase of Industry 4.0 are also identified. Then, various examples of Industry 4.0 applications in the world are stated and also some applications in pilot sectors in Turkey are described.

In this study, it is aimed that the concept of Industry 4.0 will be discussed with examples of industrial applications and concretized the idea and guided the people by various applications who will work in this field.

\section{Literature Review}

Literature reivews indicate that studies under Industry 4.0 are grouped under four main headings. These titles are; Cyber Physical Systems, Internet of Objects, Internet of Services and Smart Fabrics.(Kagerman et al.,2011).On the other hand, the report "Recommendations for Implementing the Strategic Initiative Industry 4.0 " by the Industry 4.0 Working Group is the report that was presented to the German government in 2013 (Kagerman et al., 2013).In addition, the study entitled "Industrie 4.0 in Produktion, Automatisierung und Logistik: Anwendung - Technologien - Migration" (2014) by B. Vogel-Heuser, M. Ten Hompel, T. Bauernhansl is another important source published on this field.

Similar ideas have been put forward by the article "Industrial Internet" (Bungart, 2014; Evans \& Annunziata) published by General Electric in 2012 for the idea of Industry 4.0, which has not reached a level of awareness outside Germany.

In the "Industrial Internet Consortium, 2013 the concept of Industry 4.0 is defined as the combination of physical complex machines and instruments with interrelated sensors and software to achieve better results. 
Similar work on Industrial Internet is accepted as "Integrated Industry" (Bürger \& Tragl, 2014) and "Smart Industry, manufacturing intelligence and demand-dynamic performance " (Davis et al., 2012).

The study entitled "Industrial 4.0 Economic Perspective as a Requirement for Turkey's Global Competitiveness" T / 2016-03 / 576 prepared by TUSIAD is one of the most comprehensive publications prepared in Turkey.

The study presents evidence based on scientific evidence that why Industry 4.0 has today viable and vital . In addition, the potential effects of Industry 4.0 on Turkey have been researched and findings have been revealed.

The book "Endüstri 4.0" (Gorcun, 2016), prepared by the Beta publications, details the phases of industrial revolutions in the chronological order, ranging from Industry 1.0, Industry 2.0, Industry 3.0 and Industry 4.0.

"Endüstri 4.0 ve Akıllı İşletme" (Banger, 2016) another work prepared in Turkey, the subjects such as Internet of Objects, Intelligent Business, Smart Production, Intelligent Factory, new multifunctional technologies and new situation of workforce are discussed.

On the other hand, the book entitled "The Fourth Industrial Revolution" (Schwab, 2016), published by the founder and chairman of the World Economic Forum in February, reveals in detail how to understand and shape the new technological revolution, including the transformation of mankind.

\section{Industry 4.0}

Since the beginning of the industrial revolution, three main stages have been achieved thanks to technological developments and each step has affected industrial efficiency substantially.

At the end of the 18th century, steam powered machines began to be used and by the early 20th century, mass production was possible with electric energy. From 1970s automation became widespread with electronics and information technology. Nowadays, with the help of cyberphysical systems and dynamic data processing where value chains are connected end to end have begun to shift to the fourth phase of the industrial revolution (Endüstri 4.0, n.d).

There have been four major industrial revolutions throughout history.

1. Invention mechanical machines for more efficient use of water and steam power

2. Henry Ford's production line design and the use of electricity in serial production, the development of the $\mathrm{T}$ production line.

3. In the 1970s, because of the use of programmable machines in production, mechanical and electronic technologies were replaced by digital technologies

4. Industry 4.0 is an industrial strategy plan that is supposed to trigger the 4th Industrial Revolution. 
With the influence of factors such as cyber-physical systems, the Internet of Objects and Services and innovations have begun the Fourth Industry Revolution.

Industry 4.0 is based on 6 basic principles in generally (Hermann \& Pentek,2015).

1) Interoperability: It involves the ability of humans and smart factories to communicate with each other through the Internet of objects and services with the help of cyber physical systems.

2) Virtualization: This is a virtual copy of intelligent factories. The system consists of connecting sensor data with virtual plant and simulation models.

3) Decentralization: The ability of cyber-physical systems to make their own decisions within smart factories.

4) Real-Time Ability: Ability to collect and analyze data. This structure enables quick understanding.

5) Service Orientation: Cyber-physical systems, people and intelligent factory services are offered through the Internet of Services.

6) Modularity: Provides a smart factory flexible adaptation system for the changing requirements of individual modules.

\section{Structure Of Industry 4.0}

Industry 4.0 is a combination of technologies and value chain organizations. This system is based on the concept of cyber-physical systems, the internet of objects and the internet of services. This structure contributes greatly to the vision of smart factories. Industry 4.0 consists of the following 3 main principles in generally (Kesayak, n.d.).

- Internet of Objects

Internet of Services

- Cyber-Physical Systems

With industry 4.0, modular smart factories are aimed at tracking physical processes with cyberphysical systems, creating a virtual copy of the physical world and making decentralized 
decisions. The cyber-physical systems and objects of internet will be able to communicate with each other and people in real time and cooperation.

Both internal and cross-organizational services will be offered by the Internet of services and will be evaluated by users of the value chain (Tansan \& Gökbulut, 2016).

\subsection{Big Data \& Analysis}

Analysis methods which utilize big data groups that are being used in production increase the quality of production, save energy and facilitate equipment maintenance. When evaluated from Industry 4.0, it is expected that the collection and comprehensive evaluation of data from many different sources, such as institutional systems and customer-based management systems as well as production systems will become standard in real-time decision making (Tansan \& Gökbulut, 2016).

\subsection{Smart Robots}

Manufacturers in various sectors benefit from robots in their processes for a long time. In the world, robot technology develops its skills and becomes more autonomous, flexible and cooperative and also reduces the cost of ownership.

In the following period, the interaction of robots will be increased. In addition, robots and people will be able to work side by side more secure than before. In addition, efforts are being continued to improve the learning capabilities of the robots (Tansan \& Gökbulut, 2016).

\subsection{Simulation}

Nowadays, 3D simulation of products and materials is already utilized in the design phase but simulations will become more common in factory operations in the future. In these virtual models, which are prepared using real-time data, virtual reality of the physical world can be created together with machines, products and people.

Operators will have the opportunity to test the machine parameters for the following product in the production line by simulation before actually doing it. This will shorten the installation time and increase the quality of the product (Tansan \& Gökbulut, 2016).

\subsection{Vertical and Horizontal System Integration}

At present, most information systems do not consist of fully integrated Systems. Companies, suppliers and customers generally do not work completely dependently of each other. The same condition is valid for engineering design, production and service functions.

However, as global data integration networks evolve, companies, units and competencies will become more compatible with one another and productivity values will increase (Tansan \& Gökbulut, 2016).

\subsection{Internet of Objects}

Nowadays, only a part of sensors and machines benefit from integrated data processing by connected to the network. Generally, sensors and devices with limited artificial intelligence and 
automation control mechanisms are defined as vertical automation pyramids, which are connected to the central production control system.

When the internet of objects is applied, this will enable more and more devices to connect to each other with standard technologies and benefit from integrated data processing. In this way, equipment in the shop floor can communicate with each other and with central control systems if necessary. It will also enable real-time decision-making by eliminating the one-handed analysis and decision-making process (Tansan \& Gökbulut, 2016).

\subsection{Cyber safety}

Some companies still use management and production systems that are not interconnected. However, as the availability of connected systems increases, secure communication will begin to gain importance in order to protect critical industrial systems and production lines against the threats of cyber security. As an example, last year various industrial hardware suppliers joined forces with cyber security companies through partnership or acquisitions (Tansan \& Gökbulut, 2016).

\subsection{Cloud Computing}

Companies use cloud-based software for some analytic applications. However, in the coming period, more data about the products will need to be shared between the plants and the companies. At the same time, due to the increased performance of cloud technologies, the response time will be reduced to a few milliseconds. As a result, the data and functions of the machines in the cloud platforms will be increased and more services based on the data will be available to the production systems. Today, companies that manufacture execution systems are already offering similar cloud-based solutions (Tansan \& Gökbulut, 2016).

\subsection{Additive Manufacturing}

Additive manufacturing is one of the most critical manufacturing technologies today. There are many types of additive manufacturing that can be classified according to the material used (liquid, powder, solid or gas). These include laser melting of metal powder, melting by laser beam stacking electron beam, layered adhesive production, melt deposition modeling technique, scanning curing by light. At the beginning of 1990s, the additive manufacturing technologies were used to make more visual models, prototypes to see that parts are in place and work properly etc. Now, working in many sectors concentrates on direct part production (Wohlers, 2013). Direct part manufacturing has been around 30\% today, with a rapid change in total additive manufacturing since 2000's. It is estimated that this ratio will reach $50 \%$ by 2020 (The Printed World, 2011). Actually, after the aviation industry's interest in this technology has increased, the industrial acceptance of layered manufacturing technologies has also accelerated.

As a result, high performance additive manufacturing systems will have an impact on reducing logistics costs and stock levels (Tansan \& Gökbulut, 2016).

\subsection{Augmented Reality}

Systems that benefit from augmented reality support a variety of services such as selecting parts in the warehouse and sending repair instructions to mobile devices. 
In the future, it is expected that companies will benefit more from augmented reality in order to improve decision-making and operational processes and to provide real-time information to their employees (Tansan \& Gökbulut, 2016).

\section{Impact of Industry 4.0}

Industrial revolutions have affected the world and societies on a global scale since the past. Production has always been an obligation for mankind and has been in search for new ways to continue production. Industrial 4.0 will undoubtedly lead to the creating of new sectors and the disappearance of the underdeveloped sectors. This situation is not only for sectors, but also for people, companies and countries. Anything that cannot keep up with the new industry revolution will be negatively affected. As an example, people who worked with arm force and then technicians started to lose their jobs and now engineers are in danger of losing their jobs. The positive effect of Industry 4.0 may partially compensate the negative effects. Although there will be employment problems, new business areas will also be created. Smart products that will be produced in smart factories will make our life easier. It is a big advantage that it will do it with less energy. By producing smart products, these products can be adapted and developed to different areas according to human needs. With 3D printers, everyone will produce simple products and it is a positive effect that manufacturer and consumer are the same. With industry 4.0 it is expected that significant improvements will be achieved in terms of marketing speed, flexibility and efficiency.

The advantages of Industry 4.0 can be summarized as follows: (Seyrek, n.d.)

- Facilitating system monitoring and diagnostics

- Self-awareness of systems and components

- Sustainable system with environmental friendly and resource-saving behavior

- Greater efficiency

Increase flexibility in production

- Cost reduction

- Development of new service and business models

\section{Risks of Industry 4.0}

It seems that in the first stage of the industry 4.0 strategy, the passing period of the hardware and software will not be a problem since there will be no difficulty when considering less energy to use for hardware and software. However, it is obvious that all of the machines to be used in production are not easy to program and adapt according to the standards of Industry 4.0.

It seems that it will take time to find solutions to problems such as disagreements between companies and shareholders who do not want to enter into business, the cost of change and the need to prevent financial problems and the integrity of production processes.

Possible risks can be classified as a three main groups within the scope of Industry 4.0; Investments, information security and qualified employees. 
Despite all these challenges and risks, the Industry 4.0 is a long way and this transition period can be passed easier with collaboration of all responsibles (KPMG, 2015).

\subsection{Investments}

Industry 4.0 seems to be a subject that can be especially focused on manufacturing companies but all players know that this new vision will bring new investments together. For many companies it is uncertain that how much investment will be returned at the first stage.

The lack of a concrete executive plan has led to the hesitant approach of companies that made big investments.

\subsection{Information Security}

Connected devices share big amounts of data via the Internet and this automatically causes potential security risks because hackers may interfere with manufacturing and logistics systems or shut down these systems. Moreover, confidential customer or supplier data may be shared with the opponents. The protection of intellectual property right and company secrets is one of the biggest challenges in this context. Loss of this information can cause the basic competence in production to be visible and threaten the position of the company in the market, its competitive advantage and its existence. In the future; innovative and high-performance information security solutions will be required to protect facilities from hacking.

\subsection{Qualified Employees}

Another important issue concerning the Industry 4.0 is the qualifications of employees and bluecollar workers. In the future, employees will need to offer higher qualifications to their companies. By integrating smart and modern information systems into production facilities, new business requirements and profiles will be developed especially in production planning, industrial engineering, quality assurance, supply chain management and production areas.

Increased use of innovative devices, smart technologies and information systems related with new business models and processes will require higher quality training for tomorrow's bluecollar workers.

\section{Global Industry 4.0 Applications}

Within the scope of Industry 4.0 applications, Siemens foresees the development of autonomous production systems with self-regulation and follow-up capability, that each component of the process flow is related to the virtual and real world and that the data generated by these processes are analyzed with big data. As an example of this strategy, it is possible to give an example named "Digital Enterprise Software" in which the product life cycle is managed. This structure aims to make software solutions that address different needs developed over the years into a full automation, is on its way to becoming Siemens' Industry 4.0 breakthrough (Aydın, n.d.).

On the other hand, Bosch company, which has a large number of pilot projects on Industry 4.0, is working on a production flow where the machines and products are aware of each other. The pilot project in the Bosch Rexroth factory in Hamburg aims to speak the same communication language as the product itself, the machine that produces it and the human factor that makes the 
follow-up. The smart production band supported by RFID technology is able to decide and process products according to their types. While components of the different products can be processed in the same line, modularity is provided and the products are open to new developments. The data generated by this complex communication network can be viewed simultaneously on the screens of workers. Bosch's next goal is specified to provide control and optimization of its production throughout the world by using a common network. At the same time, the properties of the products will be stored in their memory by utilizing the concept of Internet of Objects. This change will lead to smart production and the way to the smart factory.

Smart City, another pilot project of Bosch, is planning to create a transport network that generates data by tracking and optimizing road works and parking areas. Smart City is a mobile application for Industry 4.0 and it will be used for Monaco city firstly. Researches indicate that 37 billion objects on the world will join this ecology. The big majority of these objects will be product components in the production line (Aydın, n.d.).

Henry Ford has made the process more manageable by incorporating the entire plant into the workflow with the production line he invented. In this century, producers have to deal with both the consumers and the logistics part. T-Systems, a Frankfurt-based telecommunications company, is working on a CRM service that will manage the smart factories of the future.

The system is defined as a comprehensive solution for the follow-up of the process from the most basic steps of production to the end user. With the software named "Arrival Control", TSystems will be able to meet to the need for a tracking and analysis problem with the widespread availability of smart factories (Aydın, n.d.).

\section{Industry 4.0 Applications in Turkey}

In this section, applications which are used in various companies and which can be evaluated within the scope of Industry 4.0 are explained in detail.

\subsection{Smart Robots}

In a company, tool changes were made by the operator in the non-conventional machines. If more than one tool is used in an operation, the wrong tool / guide mounting problems are frequently encountered. This may lead to scrap of the parts. In the new CNC 7 axis hole drilling machine, electrode and guide change is made with a Fanuc robot which adapts to the machine externally. In this application, when the need of tool change occurs, robot jaws goes to the carousel area and make the electrode/guide change by using specific commands in the CNC program. Robot jaws comes to the tool number that is specified in the program. There is a reader on the tool which specifies the tool number. The chip on the tool is read by the Balluff sensor on the robot. The Balluff sensor on the robot confirms that the specified tool in the program is selected and prevents the wrong tool from being used. If wrong tool wants to be used, the robot gives an error message. With this application there is no need to the operator during tool change and operation becomes error-proof. 


\subsection{Simulation- Virtual Reality}

In a company, conventional and non-conventional machining operations are usually performed by CNC controlled machines. CNC program codes for part processing are prepared by computer aided manufacturing programs. If a CNC program for a part machining is not confirmed with a simulation program before it is tried on the machine, the tool may touch to the workpiece or machine head crash into the workpiece. In addition, the areas which has restricted accessibility cannot be detected before part processing. In case of any crash in the machine, the axis precision is distorted and geometric alignments have to made again to bring the axis repeatability back to the desired values. In addition, axis sensitivities are verified by laser measurement and this causes a labor loss at least 1 week.

For the new CNC machines, both programming and simulation modules have been purchased and thanks to this simulation module, the CNC program can be verified before manufacturing and any possible faults, access restriction etc. can be detected before the process. In this way, $\mathrm{CNC}$ program can be tried off-line without being tried on the machine and possible errors can be corrected easily. In the simulation program, the machine, the part and the fixture can be modeled and the machining operation can be performed exactly. In summary, processes are simulated before mass production begins.

\subsection{Internet of Objects}

In the conventional machines of a company program load was performed by USB, card reader, etc. Operators were downloading required program from the program system which was in accordance with the part and operation number. However, if a change was made in the CNC program and the programs were not taken from the system, there was a risk of processing parts with the old revision program. For this reason, the machines are connected to the program downloading system via Ethernet connection in order to make the system error-proof. This application creates a more advanced network by allowing the Internet to integrate with the machines, systems and processes within the scope of Internet of objects.

Also, this application allows the operator to automatically download CNC programs from the program system before each machining operation. This prevents the use of the old revision program and ensure that the latest revision program is always used.

\subsection{Cloud Computing}

Today, companies that manufacture execution systems are beginning to offer cloud-based solutions. Transferring systems that follow and control processes into a cloud will not be a surprise in Industry 4.0. In this company, there is an increase in the number of production quantities and new investments are being made in parallel with this.

For this reason, a line monitoring program has been prepared in order to facilitate the control of the machine in the scope of the digital production vision.

This program is running as a SQL database on the web and has been completely developed with in-house capabilities. In order to be able to get data via the program, it is necessary to make connections and settings of the machine first. With the system being activated, active working 
hours of the machine, alarms and operation data can be monitored and the CNC programs can be transferred to the machine.

Within the scope of line tracking and monitoring system studies, Sematic touch panels have been mounted on each machine. Thus, the operation pages which were previously printed in the files were transferred to the digital center.

There are a large number of CNC controlled machines in the company. It is very difficult to monitor the active working times and to be informed immediately in case of any trouble.

Thanks to the developed line tracking and monitoring system; the serial number, operation number, CNC program number and active working hours of the part being operated on any selected machine can be reached instantaneously. In addition, if there is more than half an hour of malfunction on the machine, a warning e-mail is automatically sent by the system to the department manager.

Error messages and alarms given by machine need to be analyzed in detail so that the autonomous maintenance of the machine can be planned correctly.

All error messages and alarms of the machine connected to the line tracking and monitoring system are recorded and can be reported in the desired date range. In this way, problems that become chronic can be easily analyzed and the actions to solve the problem can be taken in advance.

On the other hand; the productivity of the machine can be calculated from the active working hours of the machine connected to the line tracking and monitoring system. In the system; total working hour of the workstation is already recorded. In addition to this, the active working hours in the system are recorded; machine productivity value is calculated in terms of dividing the active working hour into the total working hour.

For each machine connected to the system, graphical representation and numerical values and productivity values results can be obtained. As a result; data are evaluated as an output for productivity and the necessary actions are taken to bring the value to the optimum level.

\subsection{Additive Manufacturing}

A company operating in the aviation sector is producing coupons by using additive manufacturing technology. Firstly, a section view of the part is obtained from part geometry. The obtained sectional view is extended by the thickness required for process verification. Then, 3D model is transferred to the additive manufacturing machine and the production is performed. This simulated part is used for process tests and verification and the necessary values for process approvals are obtained from metallographic inspection of this part. Thanks to this, the cost of testing studies has been reduced considerably and a significant run hour reduction has been achieved in the process development.

In aviation sector; prototype parts must be manufactured in order to perform engine performance tests. Depending on the performance data obtained on the prototype engine, the model of the engine parts can be changed. Every change in the engine design causes the change in the fixtures, tools, inspection gages and as a result the total cost of the project increases. 
Production can be performed with nickel-based super alloy powder in additive manufacturing machine for the combustion chamber part which has very complex geometry.

The advantages and disadvantages of these samples are examined in terms of material strength and properties. The metallographic results obtained so far show that the samples have better properties than the casting material and lower quality than the forging material (Yiğit et al., 2008).

\subsection{Smart Inspection Tools}

True position inspection of work pieces in the machining industry are usually performed on CMM machines. The tolerances in the parts drawings are very tight due to the requirements of the sector. For this reason, the parts may need to be inspected in restrained conditions. With the Renishaw probe system, it is possible to take measurements from the part while it is processing in the machine. This method allows the inspection of the part without any deterioration while removing the part from the fixture and there is no need to set-up the part again for inspection. At the same time, during the set-up of the part, flatness and run-out can be adjusted to the required values by this method. Each inspection can be confirmed with the prepared macro programs to make sure that the part is within the blue print limits.

\subsection{Visual Factory}

Visual management is one of the important method of ensuring that information flows correctly and effectively. It is one of the biggest assistant tools for monitoring and managing the performance.

Visual management is also referred to as the visual factory. Visual management tools are the administrative tools that show the sequence of the projects, the workload capacity of the workstations, the instantaneous performances and the planned \& actual situation. There are many applications such as Andon light, road line, emergency exit, production quantity indicator, occupational safety warning. In the automotive companies, the workstations are divided into cell production units on the basis of visual management. In order to see the difference between the planned and actual situation of the cells and to take permanent actions to the problems, the visual boards are prepared at the end of each day and the evaluation is done with the daily meetings every morning.

Another tool for the visual management is machine monitoring systems. Although the CNC commands are used for axis movements, the instantaneous change of the machine parameters must be followed during processing. Previously, the machine parameters were manually controlled by the operator during cutting. In the scope of visual factory studies a system that controls the feed of the CNC machines was adapted by the "Caron Engineering" company. To activate the system, an ammeter is installed on the engine drive of the machine.

This sensor keeps the load within certain limits by calculating the load. In this way, when the tool is subjected to overload, the software pulls the tool back to optimize the load and prevent the tool from breaking. The system has the learning mode. If several pieces are cut at nominal speeds and the system learns the limits of optimum conditions. After that, the feed limit is set according to the load values taken from the memory of the device. If the specified range values are exceeded, the program interfere with the machine and the feed value is reduced. 
With this application, it is ensured that the tool always operates with the optimum load by avoiding the overloading of the machine.

\subsection{Smart Storage Systems}

A company operating in the metalworking industry has different cutting tools, milling and reaming sets, inspection gages, electrodes, guides, etc. for each operation and specific to each different part. Due to the variety of the parts and operations, all consumable materials must be properly classified and must be supplied within a short period of time by the toolcrib. For this purpose, they have Kardex vertical storage systems in the company. In this system, operator makes a request from the storage system with the material code number. The device has the feature of automatically selecting the product by going to the relevant shelf from the stored material groups. The operator can continue the processing by taking the related product from the opened window. The decrease in the SAP system of the product is made automatically by the Kardex which enables instant and accurate stock follow-up.

The advantages of the system are faster access times to products, increased product turnover, more storage space on a much smaller area and integration into ERP systems to ensure instant and accurate stock availability.

Another smart storage system is tool vending machines which are connected to the document management system. Storage units can be used alone or together and offer secure inventory control, accountability of tool usage, and flexibility in storage options. The operator can get the consumable material requested by the document management system on his own without the need of anyone thanks to the automatic opening of the shelves. The decrease in the SAP system of the product is made automatically by the vending machines. Another advantage of this system is that it provides automatic inventory report output, in which new purchase orders are automatically created by detecting materials falling below the critical stock amount. With this way there is no need to manually follow orders for materials falling below the critical stock amount. Thanks to the positioning of these systems beside the work stations, reduction in consumable material waiting time can be achieved because operators can demand the requested material from the tool vending machines and instantly access the requested material.

\section{The Effects of Industry 4.0 Applications on Productivity and Cost}

At the end of 2016, the maximum run hour reduction was obtained in the division where Industry 4.0 applications were mostly applied. (see. Graph-1) 


\section{icalangme}

$2^{\text {nd }}$ International Conference on Advanced Research in

MUNICH, GERMANY

BUSINESS, MANAGEMENT \& ECONOMICS

6 - 8 DECEMBER, 2019

Graph-1: Run Hour Reduction

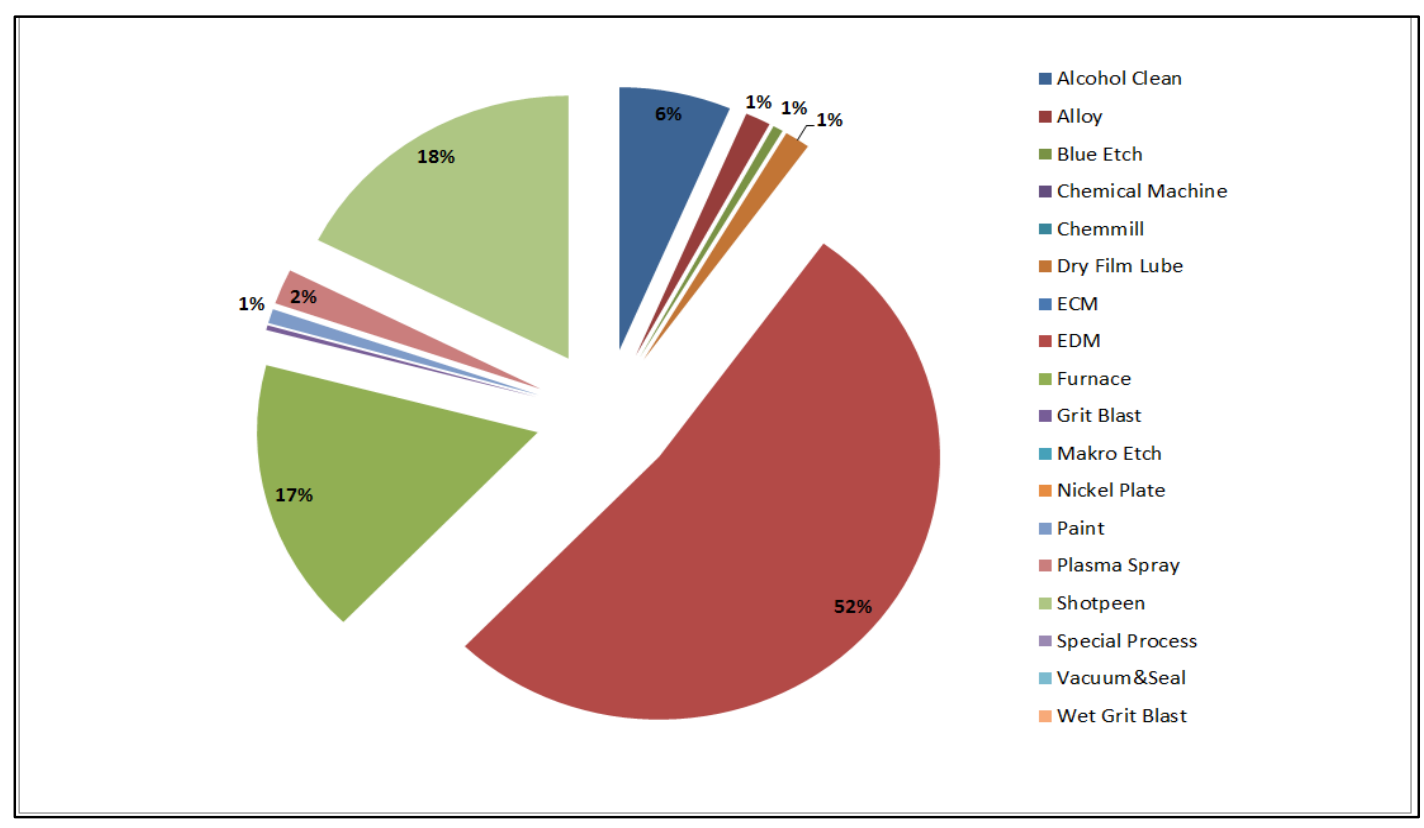

With the help of the Industry 4.0 activities, a significant reduction in the rework hours has been obtained. (see. Graph-2)

Graph-2: Rework Hours

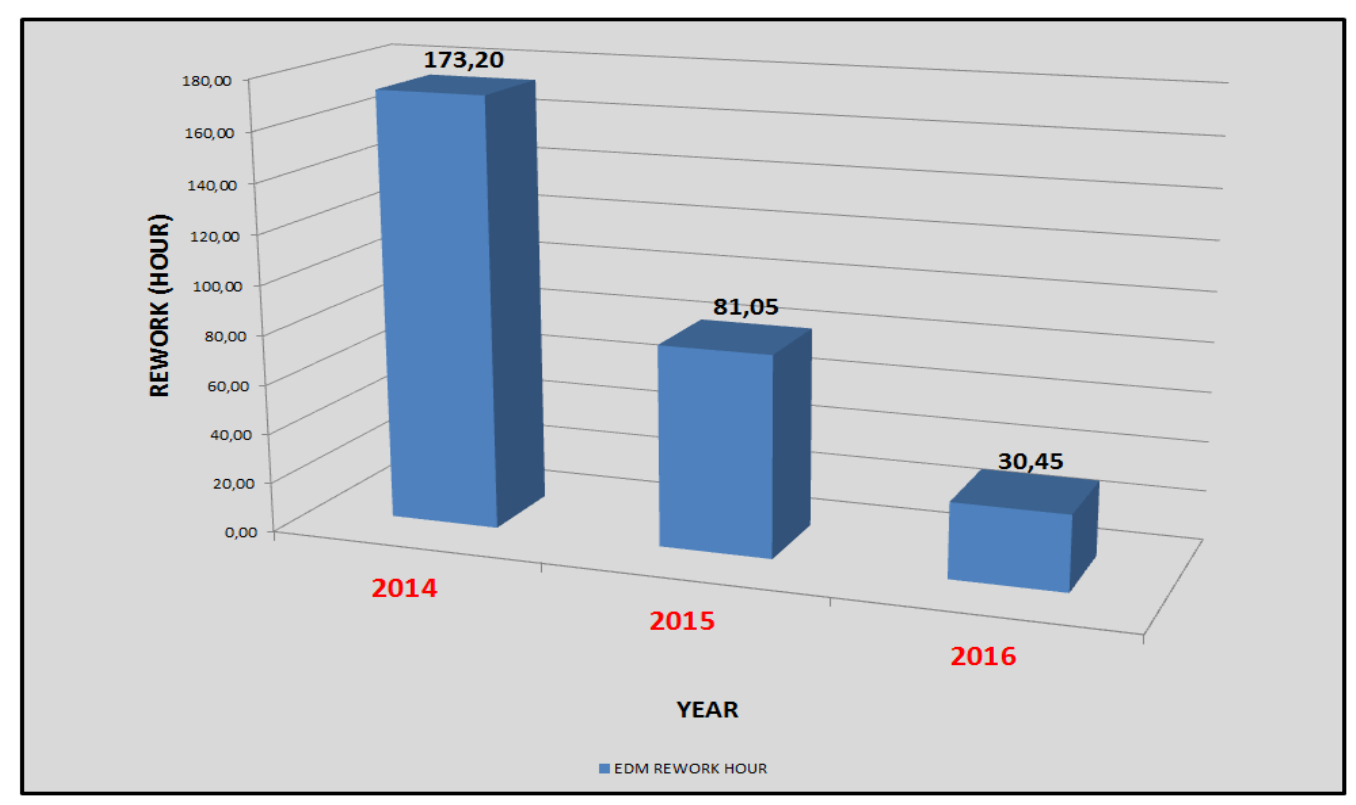




\section{icalunge}

$2^{\text {nd }}$ International Conference on Advanced Research in

MUNICH, GERMANY

BUSINESS, MANAGEMENT \& ECONOMICS

6 - 8 DECEMBER, 2019

As a result of the Industry 4.0 activities, a great reduction in the MRB line has been achieved. (see. Graph-3) Line item must be created when the inspection results of the part exceed the tolerance given in the technical drawing. At this stage, the defect is shared with the design team and the part can be sold if it is accepted by the customer.

Graph-3: MRB Line Item Quantity

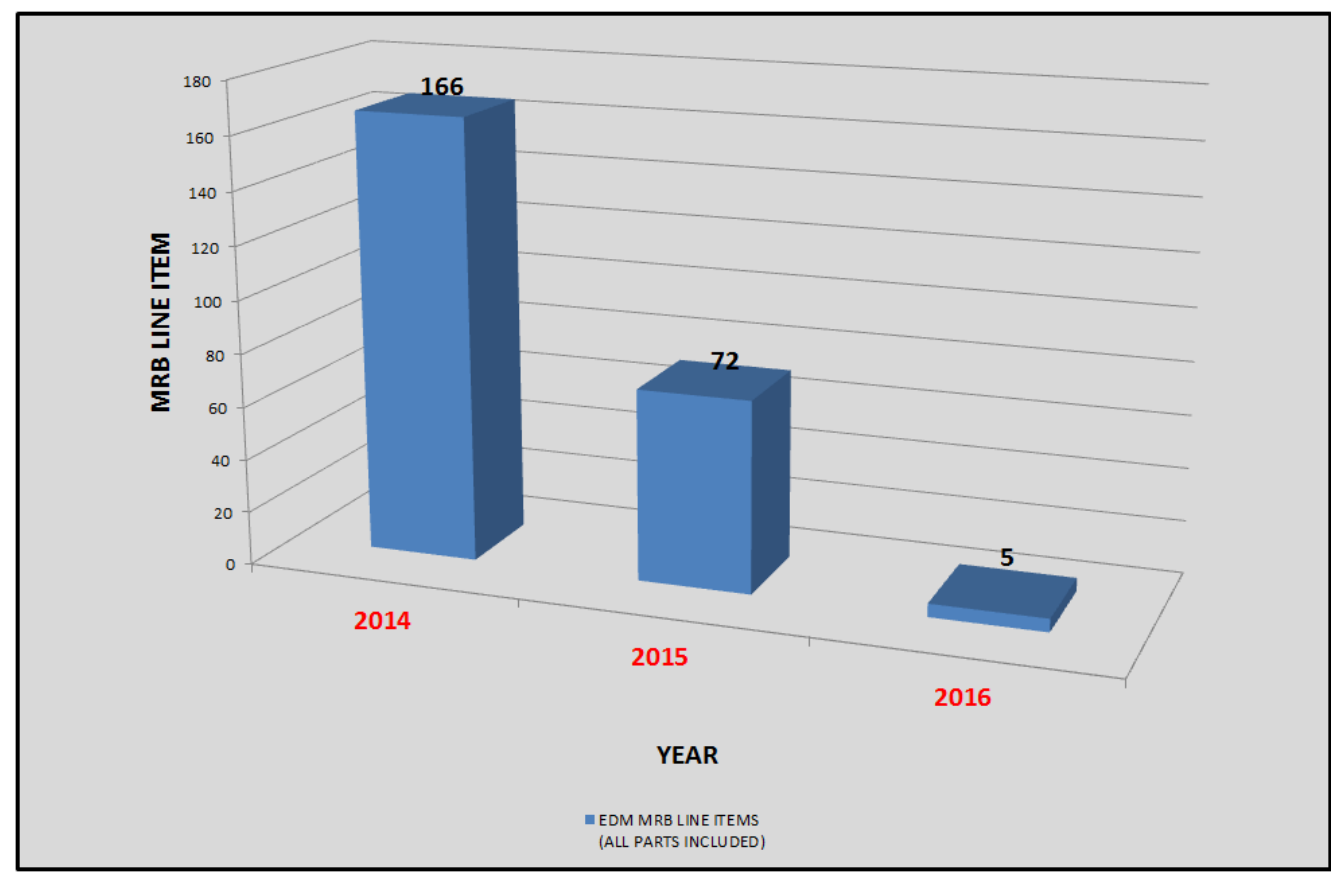

After the installing of technological investments, there is a major run reduction in machine hours of the parts (see. Table-1).

Table-1: Run Reduction After Technological Investments

\begin{tabular}{|c|c|c|c|c|c|}
\hline PART NUMBER & OPERATION & $\begin{array}{c}\text { WORK } \\
\text { STATION }\end{array}$ & $\begin{array}{c}\text { MACHINE } \\
\text { HOUR } \\
\text { (BEFORE) }\end{array}$ & $\begin{array}{c}\text { MACHINE } \\
\text { HOUR } \\
\text { (AFTER) }\end{array}$ & $\begin{array}{c}\text { RUN } \\
\text { REDUCTION(\%) }\end{array}$ \\
\hline 13910-XXX-XXX & 155 & $11021 \& 10228$ & 15,0 & 4,0 & $-73,33 \%$ \\
\hline XXXXM93G09/G10 & 400 & $11021 \& 10228$ & 14,0 & 4,0 & $-71,43 \%$ \\
\hline XXXXM72G03 & 270 & $11021 \& 10228$ & 13,5 & 3,75 & $-72,22 \%$ \\
\hline XXXXM12P04 & 200 & $11091 \& 10263$ & 0,8 & 0,4 & $-50,00 \%$ \\
\hline XXXXM10G01 & 320 & $11091 \& 10263$ & 21,5 & 5,75 & $-73,26 \%$ \\
\hline XXXXM78P09/P10 & 70 & $11091 \& 10263$ & 3,0 & 1,0 & $-66,67 \%$ \\
\hline TPXXXXXX & 40 & $11091 \& 10263$ & 31,7 & 7,5 & $-76,34 \%$ \\
\hline L38642XXX & $X$ & $11091 \& 10263$ & 80 & 25,0 & $-68,75 \%$ \\
\hline L38366XXX & $X$ & $11091 \& 10263$ & 80 & 45,0 & $-43,75 \%$ \\
\hline XXXXT13G08 & $X$ & $11091 \& 10263$ & 112,5 & 16,5 & $-85,33 \%$ \\
\hline
\end{tabular}




\section{Result}

As a result, each country and industry sector will start to implement Industry 4.0 with different speeds and approaches. Countries with high labor costs will create a demand for qualified employees in order to increase the share of automation in production. Turkey can take advantage of this idea with a focused, coordinated and well-designed approach that includes all shareholders. To realize this transformation, manufacturers, suppliers, politicians and academicians should be active to adopt nine technological elements that trigger Industry 4.0. The most critical factor in the development and competitiveness of the Turkish industry will be the application of the Industrial 4.0 revolution. Industry 4.0 offers a great opportunity to trigger a high value-added investment cycle. New production techniques will provide Turkey the opportunity to access the cycle of increased high value-added investment instead of low valueadded production cycle. As a result of by implementing of Industry 4.0; it is expected that the increase of global competitive power will increase the share of high added value products from the global value chain. Also, it is expected to protect and strengthen their productivity and competencies and their global competitive position.

In this context, some of the world's leading electronics companies claim that the 4th Industrial Revolution will come in 2020s. However, the results that have been experienced so far indicate that the standardization and programming of all related machines and their services is not an easy target. This shows that the Industry 4.0 will not come as soon as it is supposed.

It takes a long time for new generation machines to be coordinated and optimized instead of all the machines that provide todays production (Ege, 2014).

According to the results of this study, the applications related with Industry 4.0 have been positive effects on the productivity and cost values of the companies.

Within the scope of Industry 4.0, technological investments have resulted in major reduction in machine hours. These companies will continue to be one of the important companies in Turkey's Industry 4.0 transition period with their vision and knowledge that they have in the following period. 


\section{References}

1. AG Seyrek. (n.d.). Endüstri 4.0 Uygulama Stratejileri [web log comment]. Retrieved from www.endustri40.com/endustri-4-0-uygulama-stratejileri/

2. B Kesayak. (n.d.). Endüstri tarihine kısa bir yolculuk [web log comment]. Retrieved from www.endustri40.com/endustri-tarihine-kisa-bir-yolculuk

3. Banger, G. (2016). Endüstri 4.0 ve akıllı işletme. Dorlion, Ankara.

4. Bauernhansl, T., Ten Hompel, M., \& Vogel-Heuser, B. (Eds.). (2014). Industrie 4.0 in Produktion, Automatisierung und Logistik: Anwendung-Technologien-Migration (pp. 1-648). Wiesbaden: Springer Vieweg.

5. Bürger, T., \& Tragl, K. (2014). SPS-Automatisierung mit den Technologien der IT-Welt verbinden. In Industrie 4.0 in Produktion, Automatisierung und Logistik (pp. 559-569). Springer Vieweg, Wiesbaden.

6. Davis, J., Edgar, T., Porter, J., Bernaden, J., \& Sarli, M. (2012). Smart manufacturing, manufacturing intelligence and demand-dynamic performance. Computers \& Chemical Engineering, 47, 145-156.

7. Ege, B. (2014). 4. Endüstri devrimi kapıda mı? Bilim ve Teknik, Mayıs 2014, 26-29.

8. Endüstri_4.0. (n.d.). Retrieved August 29, 2019 from the Endüstri 4.0 Wiki: https://tr.wikipedia.org/wiki/Endüstri_4.0

9. Evans, P.C., Annunziata, M., 2015. Industrial Internet: Pushing the Boundaries of

Minds and Machines. Available at: <http://www.ge.com/docs/chapters/Industrial_Internet.pdf> [accessed 06.11.2015].

10. Görçün, Ö., F., (2016). Endüstri 4.0. Beta, İstanbul.

11. Herman, Mario, Pentek Tobias, Otto Boris (2015) "Design Principles for Industrie 4.0 Scenarios: A Literature Review", Fakültat Maschinenbau Technische Universitat Dortmund, s.1-2.

12. Kagermann, H., Lukas, W. D., \& Wahlster, W. (2011). Industrie 4.0: Mit dem Internet der Dinge auf dem Weg zur 4. industriellen Revolution. VDI nachrichten, 13(1).

13. Kagermann, H., Wahlster, W., \& Helbig, J. (2013). Recommendations for implementing the strategic initiative Industrie 4.0: Final report of the Industrie 4.0 Working Group. Forschungsunion: Berlin, Germany.

14. KPMG. (2015). Dördüncü Sanayi Devrimi, Yarının Fabrikaları Neye Benziyor? Retrieved from https://home.kpmg/content/dam/kpmg/tr/pdf/2016/08/tr-sanayi-4.PDF.

15. N Aydın. (n.d.). Almanya'nın Endüstri 4.0 Vizyonu. [web log comment]. Retrieved from www.endustri40.com/almanyanin-endustri-4-0-vizyonu/

16. Schwap, K., (2016). The fourth industrial revolution. World Economic Forum, New York. 


\section{icalingme}

$2^{\text {nd }}$ International Conference on Advanced Research in

17. Tansan, B. ve Gökbulut, A. “Türkiye'nin Küresel Rekabetçiliği İçin Bir Gereklilik Olarak Sanayi 4.0 Gelişmekte Olan Ekonomi Perspektifi”, TUSIAD-T/2016-03/576, s.25-45, İstanbul 18. The Printed World, (2011). Special Technology Report, The Economist.

19. Wohlers Report (2013). Additive Manufacturing and 3D Printing State of the Industry, ISBN 0-9754429-9-6.

20. Yiğit O., Dilmeç M., Halkacı H. S., 2008, Tabaka Kaldırma Yöntemi ile Kalıntı Gerilmelerin Ölçülmesi ve Diğer Yöntemlerle Karşılaştırılması, Mühendis ve Makina, Cilt:49, Say1:579 